\title{
A Strategy for Reducing Methane Emissions
}

Judith Bates, AEA Technology plc

156 Harwell, Didcot, Oxfordshire, OX11 ORA, UK.

\begin{abstract}
Methane is an important greenhouse gas whose concentration in the atmosphere has more than doubled since pre-industrial times. It is a more potent greenhouse gas than carbon dioxide, but due to its shorter atmospheric lifetime (of 12 years) it is estimated that global emissions would only need to be reduced by about $8 \%$ from current levels to stabilize methane concentrations at today's levels. This is a much smaller percentage reduction than those required to stabilize atmospheric concentrations of the other major greenhouse gases, $\mathrm{CO}_{2}$ and $\mathrm{N}_{2} \mathrm{O}$.

The main source of methane emissions within the EU is the agricultural sector, where emissions arise mainly from enteric fermentation in ruminant livestock, but also from livestock manure. The other major source is landfills, while coal mining and gas production and distribution are smaller, but still significant contributions. There are a range of possible measures for the reduction of emissions from each of these sectors, varying from technological options such as the collection and combustion of landfill gas, or the recovery and use of methane from animal waste, through to more general measures, often of a longer term nature, such as a reduction in the amount of organic waste going to landfill, or a reduction in livestock numbers. For some sources there are still significant uncertainties in emission factors, which make the development and assessment of abatement options difficult. In addition, there is a lack of data on the cost-effectiveness of many actions and measures. Any strategy for reducing emissions is
\end{abstract}


thus likely to need to combine measures to encourage the deployment of proven techniques, and to encourage research into the cost-effectiveness of options, and to improve knowledge of emissions factors and processes for some sources.

This paper discusses the main options for the reduction of methane emissions and briefly summarizes the strategy paper recently prepared on this subject by the European Commission.

\section{INTRODUCTION}

Methane is an important greenhouse gas whose concentration in the atmosphere has more than doubled since pre-industrial times, rising from a pre-industrial concentration of about $700 \mathrm{ppbv}$ to a concentration in 1994 of $1720 \mathrm{ppbv}$ [1]. Over the last 20 years there has been a decline in the growth rate of this methane concentration. In the 1970's, the concentration was growing at a rate of about $20 \mathrm{ppbv} / \mathrm{yr}$ in the late 1970 's, but this fell to a growth rate of 9 to $13 \mathrm{ppbv} / \mathrm{yr}$ in the 1980's. Around the middle of 1992, methane concentrations briefly stabilized, but since 1993, the global growth rate has returned to about $8 \mathrm{ppbv} / \mathrm{yr}$.

Methane is a more potent greenhouse gas than carbon dioxide, with a global warming potential (over a 100 year time horizon) 21 times greater than carbon dioxide. However, due to its shorter atmospheric lifetime (of 12 years) it is estimated that global emissions would only need to be reduced by about $8 \%$ from current levels to stabilize methane concentrations at today's levels. This is a much smaller percentage reduction than those required to stabilize atmospheric concentrations of the other major greenhouse gases, $\mathrm{CO}_{2}$ and $\mathrm{N}_{2} \mathrm{O}$.

Total anthropogenic methane emissions in the EU in 1990 were estimated at 23 Mt [2]. This is 5 to $8 \%$ of global anthropogenic methane emissions which are estimated at between 300 to $450 \mathrm{Mt}$ [1]. While methane emissions in the EU are much lower than $\mathrm{CO}_{2}$ emissions (Table 1), the higher global warming potential of the gas means that in global warming terms its emissions are significant, particularly if a short time horizon is considered. 
Table 1. Anthropogenic Emissions of $\mathrm{CO}_{2}, \mathrm{CH}_{4}$ and $\mathrm{N}_{2} \mathrm{O}$ in the $\mathrm{EU}$ in 1990

\begin{tabular}{llllll}
\hline & Emissions & $\begin{array}{r}\text { 20 year time horizon } \\
\text { Mt of } \mathrm{CO}_{2} \\
\text { Equivalent }\end{array}$ & GWP & $\begin{array}{l}100 \text { year time horizon } \\
\text { Mt of } \mathrm{CO}_{2}\end{array}$ \\
\hline $\mathrm{CO}_{2}$ & 3,361 & 1 & 3,361 & 1 & 3,361 \\
$\mathrm{CH}_{4}$ & 23 & 56 & 1,303 & 21 & 488 \\
$\mathrm{~N}_{2} \mathrm{O}$ & 1 & 280 & 266 & 310 & 294 \\
\hline
\end{tabular}

Source: [2]

The Framework Convention on Climate Change requires (Annex 1) signatories to seek to stabilize emissions of greenhouse gases at 1990 levels by 2000. Negotiations have already begun over emissions targets for post-2000, and the second Conference of the Parties which met in Geneva in July 1996 agreed that developed countries should negotiate 'quantified legally-binding objectives for emissions limitations and significant overall reductions within specified time frames, such as 2005, 2010, 2020'. It is planned to agree these limits at the next Conference of the Parties in Kyoto, Japan in December 1997.

In considering their initial commitment under the Convention, attention, both within the $\mathrm{EU}$ and internationally, has generally been focused on policy options for reducing emissions of carbon dioxide. However, increasing attention is now being paid to potential options for reducing methane emissions, partly because uncertainty over the importance of the various sources of methane has decreased. Interest is likely to continue to grow, if the 'basket' approach, whereby reductions in emissions of the direct greenhouse gases are weighted by their global warming potential, is adopted for future emission targets.

\section{METHANE EMISSIONS IN THE EU}

Estimated anthropogenic emissions of methane by sector in the EU in 1990 are shown in Table 2. The main source is the agricultural sector, which was responsible for $45 \%$ of 
anthropogenic emissions. These emissions arise principally from enteric fermentation in the digestive tract of ruminant livestock (cattle and sheep), but also from the anaerobic decomposition of livestock manure. The other major source is landfills, where the anaerobic decomposition of organic waste in the landfill leads to the release of landfill gas, which is a mix of $\mathrm{CO}_{2}$ and $\mathrm{CH}_{4}$. Coal mining and gas production and distribution are smaller, but still significant contributions. There is significant uncertainty attached to some of the emissions estimates, particularly those arising from landfill sites.

The estimation of methane emissions from natural sources is subject to high uncertainty, but nonetheless, natural emissions are thought to be significant. Globally, they are considered to be at least $20 \%$ of total emissions, and in the EU, natural emissions, mainly from wetlands and peat based soils, were estimated to be $9 \mathrm{Mt}$ in 1990 [2]. This is almost $30 \%$ of total EU emissions.

Table 2. Main Sources of Anthropogenic Methane Emissions in the EU in 1990

Sector Emissions \% of total Of which:

\begin{tabular}{lcclc}
\hline Agriculture & $10.2 \mathrm{Mt}$ & $45 \%$ & $\begin{array}{l}\text { Enteric fermentation } \\
\text { Livestock manure }\end{array}$ & $\begin{array}{l}30 \% \\
15 \%\end{array}$ \\
\hline Waste & $7.3 \mathrm{Mt}$ & $32 \%$ & $\begin{array}{l}\text { Landfills } \\
\text { Waste water treatment }\end{array}$ & $\begin{array}{l}31 \% \\
\end{array}$ \\
& & & & $1 \%$ \\
\hline Energy sector & $5.3 \mathrm{Mt}$ & $23 \%$ & Coal mining, transport and storage & $11 \%$ \\
& & & Gas production and distribution & $9 \%$ \\
& & & Stationary combustion & $2 \%$ \\
& & & Transport & $1 \%$ \\
& & & & \\
& & & &
\end{tabular}

Source: [2]

More recent data on methane emissions from the CORINAIR database for 1994, which will allow a comparison of 1990 and 1994 methane emissions for the EU as a whole, was not available at the time of writing this paper ${ }^{* * *} .1994$ emissions data is already

1. Preliminary CORINAIR data for 1994 has subsequently become available and indicates that total anthropogenic emissions in 1994 were still $23 \mathrm{Mt}$. 
available for several Member States, and as an example, data for 1990-1994 for the UK is shown in Figure 1. This shows that UK anthropogenic emissions are estimated to have fallen by 13\% between 1990 and 1994 [3]. This is due mainly to a reduction of almost $60 \%(435 \mathrm{kt})$ in mining emissions as a result of a decline in coal production. There has also been a significant reduction of $100 \mathrm{kt}(5 \%)$ in emissions from landfill sites, due to the increased deployment and use of methane recovery systems. Smaller reductions occurred in emissions from ruminants $(13 \mathrm{kt})$, due to a fall in the number of dairy cattle, and in emissions from stubble burning (12 kt), as this is now banned. Some of these trends e.g. a decline in coal production and hence in methane emissions, and a reduction in dairy cattle numbers, are expected to be replicated in other Member States.

Figure 1. Anthropogenic Methane Emissions in the UK (1990-1994)

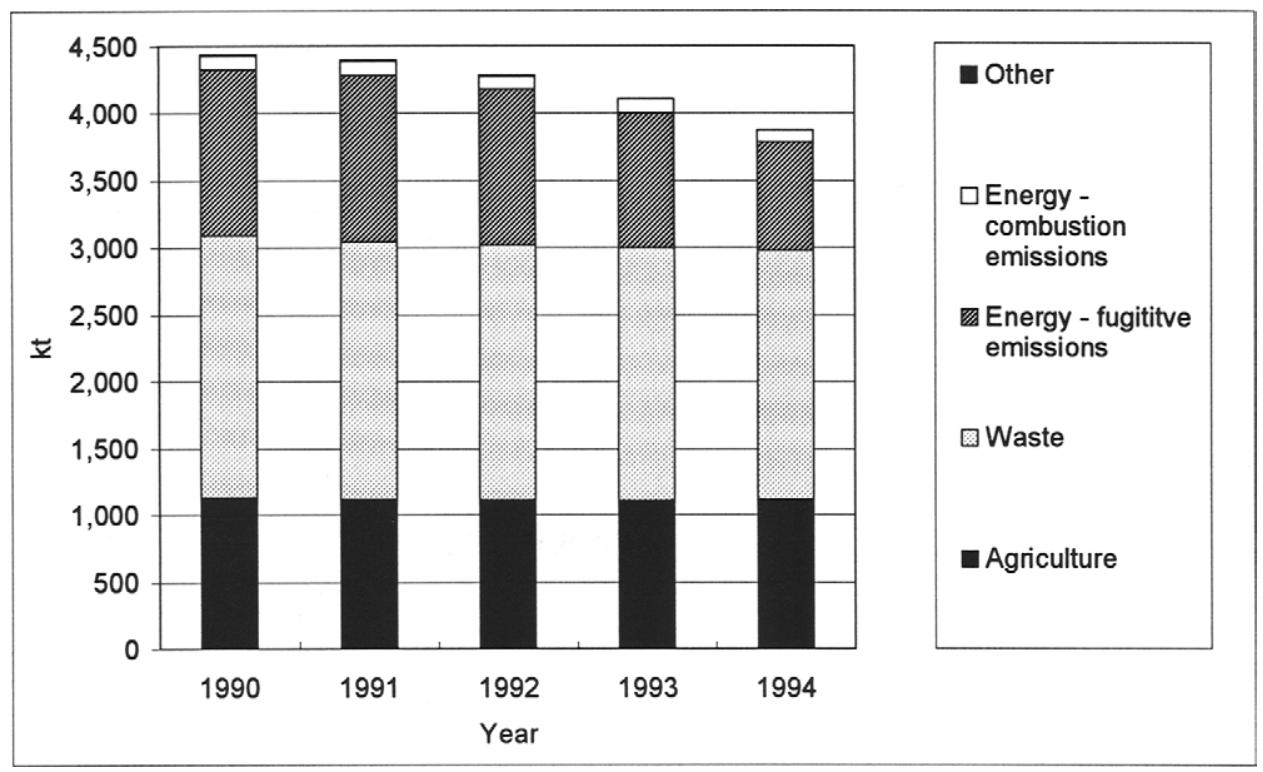

Source: [3] 


\section{OPTIONS FOR REDUCING EMISSIONS}

\subsection{Agriculture}

\subsubsection{Reducing Emissions from Enteric Fermentation}

In ruminant animals (e.g. cattle, sheep), microbial fermentation in the large stomach or rumen, breaks down complex vegetable matter into products which can be utilized by the animal. The fermentation process also produces methane, which is then eructed or exhaled by the animal. There are three broad options for reducing emissions from this source:

- Reduction of livestock numbers: this is perhaps the most obvious, and while it will produce 'real' savings, if the reduction in livestock numbers corrects overproduction of meat or milk, there is a danger that if restrictions lead to a reduction in useful output, then there may simply be a transfer of production to other countries. If this is in countries where animal productivity is not as high, and/or slurry treatments mean that slurry emissions are higher, then there may be a net increase in emissions.

- Improving the efficiency with which feed is converted: the conversion of feed to methane rather than to products which the animal can utilize represents a loss in feed efficiency. Ensuring that animals have a diet which contains sufficient nutrients and which has a high digestibility, and, can minimize methane production. Within Europe however, much has already been done to maximize the efficiency with which animals convert feed, and there may thus be little potential in the short term to reduce emissions by improving animal diet.

- Increase animal productivity: Animal productivity can be enhanced by adding production enhancing agents to feed or by injecting animals with steroids. However there is some opposition to this, and it has been banned in some EU countries (e.g. The Netherlands, Denmark and Germany). Improvements in breeding and perhaps, in the future, genetic technologies may lead to increases in productivity. 


\subsubsection{Reducing Emissions from Manure}

In animal wastes which are kept in anaerobic conditions, the fermentation of the organic substrates in the waste by methanogenic bacteria produces methane. Methane emissions from this source are thus highly dependent on how the animal wastes are handled. When manure is stored or treated as a liquid in a lagoon, pond or tank, it tends to decompose anaerobically and produce a significant amount of methane. When manure is handled as a solid or when it is deposited on pastures, it tends to decompose aerobically and little or no methane is produced.

Options for reducing emissions from liquid slurry systems include:

- Covered lagoons: In intensive livestock facilities, wastes are commonly washed from the animal shed into large lagoon ponds. By covering the lagoon with an impermeable cover (e.g. a plastic cover) methane generated in the lagoon may be trapped, recovered, and used for heat or power generation on the farm.

- Anaerobic digestion with flaring or utilization of methane: Digesters are reactors specially designed to enhance the anaerobic decomposition of waste and thus maximize the production of methane. The methane drawn off from the digester may be either flared, or used for heat or power generation. Digesters for farm waste can range from small scale digesters, suitable for a single farm to large scale digesters, often heated and operating on a continuous rather than batch process, taking waste from several farms. Such large scale digesters can also receive organic waste from other sources such as industry. The solid waste residue can be used as a soil conditioner, or further processed into a peat-substitute compost suitable for horticultural applications, thus providing income.

\subsubsection{Cost and Applicability}

Several covered lagoons are operating successfully in the US at large scale cattle or pig farms. Data from these suggests that if the recovered methane is utilized for heat or power generation on the farm, then abatement costs are in the range of -120 to 130 ECU/t methane, i.e. in some cases the plant could provide cost savings for the farm. [4]. In the case of anaerobic digestion, some EU Member States have begun to promote this technology, often as part of programs to encourage and promote renewable energy 
sources. Denmark has run an Action programme for Centralized Biogas Plants (1988 -1995), and a number of anaerobic digestion plant are now installed. The UK also has some anaerobic digestion plant, partly encouraged by the NFFO scheme, which provides a premium price for electricity generated from renewable energy sources. UK estimates of the cost [5] of abating emissions using a large scale anaerobic digesters are in the range of -90 to $90 \mathrm{ECU} / \mathrm{t} \mathrm{CH}_{4}$ (at a 5\% discount rate) depending on cost assumptions, cost of transport of waste, and income for electricity generated and residue produced. A Dutch study also found that such schemes could generates a net income, estimating that the cost of abatement using such plant was about $-50 \mathrm{ECU} / \mathrm{t} \mathrm{CH}_{4}$. The same study estimated that costs for farmscale digestion (at 400 to $450 \mathrm{ECU} / \mathrm{t} \mathrm{CH}_{4}$ ) were however much higher [6].

\subsection{Landfills}

When anaerobic conditions exist in a landfill, the organic component of waste (food wastes, waste from animal, garden waste, paper and cardboard etc.) is broken down by methanogenic bacteria in a complex biological process which releases $\mathrm{CH}_{4}, \mathrm{CO}_{2}$ and a number of other trace gases. At a national level emissions from this source are thus influenced by:

- The importance of landfill as a waste disposal option, and more significantly the amount of organic waste going to landfill. This varies significantly between countries in the EU.

- Landfill design. Air can move into shallow or unmanaged sites relatively easily, which inhibits anaerobic degradation. Engineered landfills designed for environmental protection usually exclude air because they are deep and have low permeability liners; hence methane generation is encouraged.

- The proportion of landfill sites at which methane is collected and either flared or utilized.

Finally the rate at which methane is produced varies significantly across the EU due to the wide variability in climatic conditions across the EU.

Some of the possible options for reducing landfill emissions are discussed below. 
3.2.1. Reducing the mass of degradable organic waste which is landfilled. A number of waste management practices are available to reduce the mass of degradable waste landfilled, and hence reduce methane emissions. These practices are prioritized in the EU's waste hierarchy [7].

1. Waste avoidance and minimization;

2. Re-use;

3. Recovery (of materials and energy)

A number of 'recovery' options are feasible, ranging from composting and anaerobic digestion of organic waste, to materials recycling e.g. of paper and card, glass, to incineration with energy recovery. The choice and appropriateness of the various re-use and recovery options is likely to be affected by a number of factors which are country and region specific, and may be different for different parts of the waste stream. Any national or regional waste management strategy is thus likely to include a number of these options.

Reducing the landfilling of degradable waste is not a short term option, as it will require major changes to waste management practices in many EU countries. In addition, it will take several years for its impact to be fully realized, as the degradation of waste which has already been landfilled will continue for many years.

\subsubsection{Collect and burn landfill gas, with energy recovery where economically beneficial} The technology for landfill gas collection and combustion, either for energy recovery or in flares is well understood and demonstrated in many Member States. In the past, gas has typically been collected from sites because of local safety risks (e.g. from explosion or fire caused by a build up of landfill methane in buildings near landfill sites) and /or to reduce local odor nuisance, but there is an increasing appreciation of the need to control emissions because of their significance as a greenhouse gas.

Gas is typically collected from a site using a series of 'wells' consisting of perforated popes which are installed round the site and are connected to 'ring main' gas collection pipes via well heads. The gas is then piped to a central blower/fan or gas compressor unit [8]. Once collected the gas may be flared, or may be used: 
for energy recovery through:

- direct use in boilers or process heating

- electricity generation (using spark ignition or dual fuel engines, or gas turbines)

- $\quad$ upgrading to substitute natural gas

- vehicle fuelling

- fuel cells

- as a chemical feedstock

Energy recovery for direct use and electricity generation is already common in some EU member states, e.g. Sweden has 55 energy recovery schemes, mostly supplying heat for district heating schemes, the $\mathrm{UK}$, has 105 projects, the majority of which are for electricity generation, and upgrading landfill gas has been demonstrated in The Netherlands, France and Germany. In the case of vehicle fuelling, prototype plants with a limited number of vehicles running have been demonstrated in the UK and France, but in the case of fuel cells, there are currently no commercial systems in operation, although there is a demonstration study in the US. While it is technically possible to use landfill gas as substitute chemical feedstock, there is no commercial application of this process and its profitability remains to be proven [8].

While the combustion of the methane, either through flaring or in the energy recovery options, converts the methane to carbon dioxide, the higher GWP of methane means that there is still a significant reduction in GWP. There are several additional environmental benefits of energy recovery over flaring, including:

- encouragement of increased efficiency of landfill gas collection, because the gas is seen as an asset;

- indirect reduction of greenhouse gas emissions through the substitution of a non-fossil fossil fuel for a fossil fuel;

- reduced depletion of fossil fuel reserves.

\subsubsection{Optimize biological methane oxidation in the cover soils of landfills}

In modern landfills, the final operational step in landfilling is the capping and final cover 
of the site. High rates of methane oxidation take place in landfill cover soils exposed to a methane flux $[9,10]$, as the methane is oxidized to $\mathrm{CO}_{2}$ and water by a group of naturally occurring soil bacteria. Research has shown that oxidation is enhanced in well drained soils with a sandy, open structure (which allows easy movement of gases), and by the addition of nutrients [11]. Ensuring that sites have well engineered cover systems on closure and that these are well maintained, thus offers a significant opportunity to reduce residual emissions not captured by a gas collection scheme. However this option has yet to be commercially demonstrated.

\subsubsection{Cost and Applicability}

A number of countries have already instigated policies to discourage the landfilling of organic waste. Indeed Germany and France have either banned or will soon ban landfilling of biodegradable waste, and in the UK, a landfill tax (at a standard rate of $\mathfrak{1 7 / t}$ of waste and a reduced rate of $\mathfrak{1} 2 / \mathrm{t}$ of inert waste) has been introduced to reflect the environmental impact of landfilling and encourage the use of options towards the top of the waste hierarchy. Several countries have also instigated policies to encourage the recovery and flaring or utilization of landfill gas at new and in some cases existing landfill sites. Indeed, within the EU12 (i.e. excluding Austria, Finland, and Sweden) electricity generation from landfill gas was over six times greater in 1994 (1.4 TWh) than in 1989 (0.2 TWh) [12].

The costs of the various options described above have been estimated [13] and are summarized in Figure 2. It should be noted that many of these costs are subject to considerable uncertainty and are likely to vary through the EU. It was assumed that organic waste which is diverted from landfill is incinerated as this is the most common option in the EU for pre-treating most biodegradable waste prior to landfilling. It can be seen that this is significantly more costly than other options, and it is not known how some of the other waste disposal options available for treating organic waste would compare.

The reduction in landfill emissions which each of the measures might bring about in the future has also been assessed [13]. It is estimated that existing policies which Members States have, or are proposing, to implement will lead to a $45 \%$ reduction in emissions 
from 1990 levels by 2010. Increased recovery and use of landfill gas could reduce emissions by about another $20 \%$, and if policies to divert waste from landfill and to optimize biological oxidation in the landfill cover were also implemented, then emissions in 2010 could be reduced by a further $20 \%$. Thus, implementing all three policies could bring down emissions from landfills to $15 \%$ of 1990 levels by 2010 .

Figure 2. Estimated Costs of Mitigating Methane Emissions from Landfills

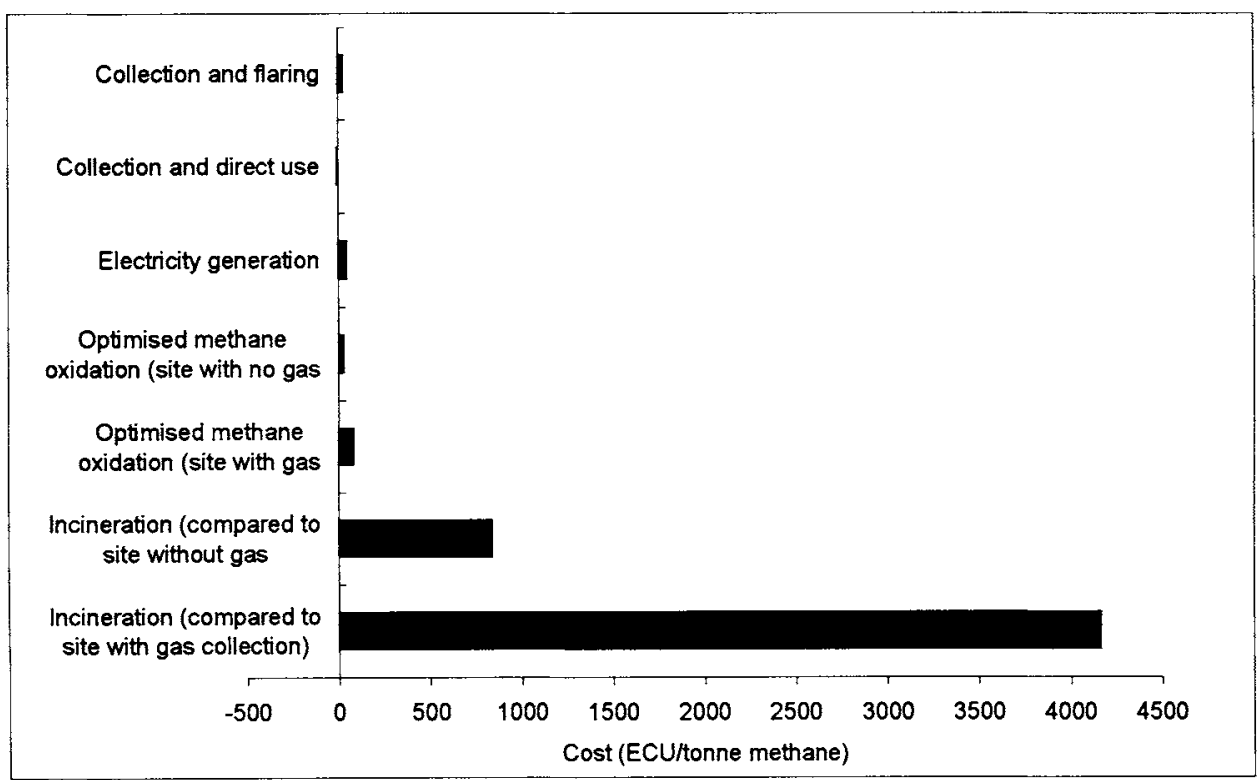

Source: [13]

\subsection{Coal mining}

Methane and coal are formed together during coalification, the process in which swamp vegetation is converted by geological and biological forces into coal. The amount of methane stored is influenced inter alia by the rank (carbon content) and depth of the coal. Higher rank coals generally have a higher associated methane content, and for a given geological setting, deep coal seams have a higher methane content than shallow ones. Much of the methane, which is trapped within the coal seam and the rock strata 
surrounding the seam, is released when the coal seam is fractured. It is then either (eventually) emitted into the atmosphere or seeps back into the mine workings as the coal is mined. Methane is explosive in concentrations of between $5 \%$ and $15 \%$ in atmospheric air, so if methane seeps into the mine workings, sufficient ventilation air must be supplied to dilute the methane to a safe level. Typical statutory limits are for a maximum methane content of 1 to $1.25 \%$.

\subsubsection{Recovery and Utilization Options}

Mine air containing methane is removed from the mine due to the risk of explosion. It is generally vented directly into the atmosphere, but, as with landfill gas, can be flared or used for energy production in a range of ways (e.g. directly in boilers, dryers, kilns and ovens, for electricity generation, for feeding into natural gas pipelines), or used as a chemical feedstock. The potential end use depends partly upon the methane content of the mine gas (and hence the extent to which it has been diluted) and partly on the proximity of potential end users and utility infrastructure.

Removing methane from the mine before it is mixed with air and extracted through the ventilation system has advantages; the gas recovered has a higher calorific value (allowing it to be used as a natural gas feed as well as for power generation) and ventilation requirements for the mine are reduced.

One option, which is widely used in two coal basins in the USA, is to drill boreholes from the surface and drain off some methane well in advance of mining. The gas obtained by this means is virtually pure methane and can be fed into a natural gas transmission system with only minimal treatment. However the technique requires a very permeable coal, otherwise a high number of holes is required per unit area, rendering recovery of the gas uneconomic. European coal is far less permeable than that at the sites in the USA, and while some trials have been carried out, results have been mixed. Methane may also be drained off before it can enter the ventilation stream in working mines. One method is to drill inclined holes into the strata above the seam and local to the working face, to connect them via a piping system and apply a small suction pressure to bring the gas to the surface. Air leakage through the coal strata, and via the many joints in the piping system, mean that the gas many contain less than $50 \%$ methane when 
it reaches the surface. Nevertheless it's calorific value is still such that it may be utilized in a number of ways, e.g. in boilers to supply space heating or hot water for mine buildings, or for on-site power generation in engines or gas turbines.

Ventilation air vented from mines must have a low methane content for safety reasons (regulations in most countries require that it does not exceed 1\%), but may contain more than $50 \%$ of the total methane emissions from the mine [14]. Upgrading the air to produce a higher quality gas is expensive and is thus not practiced. It is possible to use the ventilation air as part of the fuel air mixture in boilers or gas turbines which are located on site; if the ventilation air contains $1 \%$ methane then it would reduce the fuel requirement by up to $15 \%$. A novel approach under investigation involves passing ventilation air through a fluidised gravel-bed to combust it. In the future, lean burn technology may offer the potential to utilize this very low quality gas.

\subsubsection{Applicability of Options}

The there are only four EU countries which still mine coal in commercial quantities: Germany, UK, France and Spain. In the two most significant producers, Germany and the UK coal production has fallen significantly from 1990 levels - by $28 \%$ by 1993 in Germany [15], and by $48 \%$ by 1994 in the UK [16] - leading to a reduction in associated emissions from mining of $12 \%$ and $60 \%$ respectively [17]. In the longer term, emissions are likely to continue to fall as European coal production continues to decline; projections made by the European Commission's Energy Directorate (DGXVII) indicate that coal production in Europe will have halved by 2010 (from 1990) [18].

\subsection{Gas Production and Distribution}

Emissions can arise from every stage of the gas production and distribution chain - from exploration through production and processing to transport and distribution. Within Europe, the majority of emissions are thought to be fugitive emissions from natural gas transport and distribution, with emissions from process vents and flares being a smaller, but still significant source [19]. Options for reducing fugitive emissions include:

- improved inspection and maintenance of components such as seals, valves and connections; 
- improved pipeline inspection and leakage detection and control;

- replacement of ageing pipelines with corrosion resistant pipelines (e.g. coated steels, PVC, polyethylene).

These measures can reduce fugitive emissions by 50 to $95 \%$. While some component inspection can prove cost effective (i.e. cost are more than recouped by gas savings), a Dutch study [6] found that the cost of improved pipeline leakage control, and pipeline replacement were significant at about 1,200 and 1,800 ECU/t $\mathrm{CH}_{4}$ respectively. Countries already undertaking pipeline replacement include France, where 'Gaz de France' are planning to replace $1000 \mathrm{~km} / \mathrm{yr}$ of pipeline between 1993 and 2000, and the UK. In the latter case, British Gas TransCo has a leakage control strategy which aims to reduce emissions from the transmission network by $20 \%$ from 1992 levels by 2000 , and fugitive emissions from storage installations by $15 \%$ [20].

Emissions from process vents and flares arise for a number of reasons and from a number of sources. In oil production, gas associated with the oil must be separated off, and if there is no demand for the gas (e.g. for power generation on the platform) either vented or flared, or reinjected into the field. While venting is strictly controlled there is still some potential to flare or reinject gas rather than vent it. Other sources of emissions include offgases from processes, gas used to purge vent and flare systems, gas used for blanketing storage vessels, and 'leaks' from worn or fouled valves which do not close completely [6]. Many of these emissions may be reduced, often very cost-effectively, by improving control of processes, or small adjustments of systems, although the overall potential for reduction and overall cost is likely to vary significantly from site to site and country to country.

\section{THE EU STRATEGY PAPER}

In February 1993, the EU in its Fifth Action Programme for the Environment 'Towards Sustainability', defined a series of actions for greenhouse gases: which included the aim of possibly reducing methane emissions. In December 1994, the Environment Council asked the Commission to submit a strategy to reduce emissions of greenhouse gases 
other than $\mathrm{CO}_{2}$, in particular methane and nitrous oxide. A strategy paper for methane was produced by the Commission in November 1996, and submitted to the Council and to the European Parliament [21]. It sets out a number of potential actions in the agricultural, waste and energy sector which could be incorporated into a Community emissions mitigation strategy. These are summarized in Table 3.

Table 3. Summary of Actions Suggested in the European Commissions Strategy Paper

\begin{tabular}{lll}
\hline Source & Suggested Action & Level for Action \\
\hline Enteric fermentation & R\&D & EU and National \\
Recover methane from animal waste & 1) Demonstration & All \\
& 2) Obligation & EU \\
Reduce landfilled organic waste & Promotion of measures & All \\
Landfill gas recovery & Legislation & EU \\
Energy production from landfill gas & Incentives & EU and National \\
Mining emissions & Encourage use of best & \\
& available technologies & EU and National \\
Gas pipeline leakage & Set standard & EU \\
& Increase control frequency & National \\
& & \\
\hline
\end{tabular}

In the agricultural sector suggested measures include:

- Promoting research and incentives (at an EU and national level) to develop viable policies and measures to reduce emissions from enteric fermentation.

- Promoting the use of anaerobic digesters and covered lagoons, with collected methane preferably being used for energy production, and if not flared. It is suggested this is achieved through a demonstration programme to raise awareness and gain acceptance of the technology, followed at a later date by an EU level obligation to install such systems at larger livestock units.

In the waste sector:

- Promoting (at an EU, national, regional and local level) measures aimed at reducing the amount of organic waste going to landfill. This includes measures aimed at minimizing the generation of organic waste, encouraging separate 
collection of organic waste, recovery options such as composting and energy recovery. It is also suggested that recycled products could be promoted through economic incentives at an EU and national level.

- Introducing EU legislation requiring that new anaerobic landfills include systems to recover and utilize landfill gas.

- Introducing EU legislation to require the retrofitting of methane recovery systems to existing landfills wherever possible. Encouraging the recovery and use of landfill gas for energy production wherever possible through economic incentives at the EU and national level.

The Commission has already produced a proposal for a Directive on the landfill of waste [22], which suggests that by 2010 , biodegradable municipal waste going to landfill must be reduced to $25 \%$ of the total amount of biodegradable waste produced in 1993. The proposal also suggests that landfill gas must be collected from all landfills and either utilized, or if this is not possible, flared.

In the energy sector:

- Encouraging Member States to promote the use of best available technologies for recovering methane from mines which are expected to continue operating for a significant period of time. It is recognized that coal production (and hence methane emission from this source) is expected to continue to decline in the future, so that it may be difficult to justify additional expenditure on methane recovery in many cases.

- Setting an EU standard for allowable levels of leakage from gas transmission and distribution levels.

- At a national level increasing the frequency with which pipelines are inspected.

The measures suggested in the strategy paper reflect a number of parameters: the uncertainty in emissions arising from some sources, the state of knowledge on factors affecting emissions, whether abatement technologies are commercially available and accepted in the market place and whether options have been effectively demonstrated. They thus range from encouraging $R \& D$, through demonstration programs, to legislation 
based on what is believed to be achievable abatement levels. They also include a mix of measures which could be effective in the short term (such as the retrofitting of landfill gas recovery systems to existing sites) to measures which will may take longer to realize (such as reducing organic waste production and encouraging its diversion from landfill). It should be noted that a number of options also have additional environmental benefits: for example, the use of recovered methane from waste for energy production can reduce $\mathrm{CO}_{2}$ emissions from the combustion of fossil fuels, and the anaerobic digestion of animal wastes can help to reduce the water pollution which can occur from inappropriately stored wastes.

It has been estimated that measures such as those identified in the strategy might lead to a reduction from 1990 emissions levels of up to $40 \%$ [23], although this value is subject to considerable uncertainty.

\section{DISCUSSION}

Much further work is needed to establish more firmly the reductions which might be achieved in various sectors from different measures. There is also a need for a thorough analysis of the cost-effectiveness of the measures. The indicative costs presented in this paper show that costs for the various options can vary significantly, and that there are a number of options which might be regarded as 'no regrets' policies in that there is no net cost attached to the measure.

Table 4 attempts to broadly summarize the potential reductions which might be achieved in various sectors and gives a relative indication of their expected cost. It should be remembered that the data in the table is very preliminary; nonetheless it indicates that substantial savings might be achieved and that a number of these might be achieved at a relatively low cost. If half of the savings in Table 4 were to be achieved than this would be a reduction equivalent to $20 \%$ of total methane emissions in 1990 . 
Table 4. Indicative Costs and Potential Reductions for Methane Emissions in the EU

\begin{tabular}{|c|c|c|c|c|}
\hline \multicolumn{2}{|l|}{ Measure } & $\begin{array}{l}\text { Potential } \\
\text { Reduction }\end{array}$ & $\begin{array}{l}\text { Saving } \\
\text { (on 1990) }\end{array}$ & Cost per ton \\
\hline \multicolumn{2}{|c|}{$\begin{array}{l}\text { Enteric fermentation } \\
\text { Livestock waste }\end{array}$} & $\begin{array}{l}\text { possibly } 10 \% ? \\
40 \%\end{array}$ & $\begin{array}{l}0.7 \mathrm{Mt} ? \\
1.3 \mathrm{Mt}\end{array}$ & $\begin{array}{l}\text { unknown at present } \\
\text { low to medium }\end{array}$ \\
\hline Landfill & $\begin{array}{l}\text { - existing policies } \\
+ \text { increased recovery } \\
\text { and use of LF gas } \\
+ \text { diversion and optimi- } \\
\text { zation of oxidation }\end{array}$ & $\begin{array}{l}45 \% \text { (by } 2010 \text { ) } \\
\text { additional } 15 \% \\
\text { additional } 15 \%\end{array}$ & $\begin{array}{l}3.4 \mathrm{Mt} \\
1.2 \mathrm{Mt} \\
1.1 \mathrm{Mt}\end{array}$ & $\begin{array}{l}\text { expected to be low } \\
\text { low } \\
\text { low for oxidation; } \\
\text { could be high for } \\
\text { diversion policies }\end{array}$ \\
\hline \multicolumn{2}{|c|}{$\begin{array}{l}\text { Gas - process vents and flares } \\
\text { Gas - pipeline emissions }\end{array}$} & $\begin{array}{l}40 \% \\
45 \%\end{array}$ & $\begin{array}{l}0.01 \mathrm{Mt} \\
0.6 \mathrm{Mt}\end{array}$ & $\begin{array}{l}\text { low to medium } \\
\text { high for majority or } \\
\text { savings }\end{array}$ \\
\hline
\end{tabular}

Decline in coal production $50 \%$ (by 2010) $1.3 \mathrm{Mt}$

Acknowledgements - The author wishes to express her gratitude to several colleagues (Martin Meadows, Ian Marlowe, Alison Moore, Katie King, Allan Goode, Jacquie Berry) for their contributions and comments on this paper.

\section{REFERENCES}

1. Climate Change 1995 the Science of Climate Change, Cambridge University Press 1996.

2. CORINAIR 90, European Environment Agency.

3. UK Greenhouse Gas Emission Inventory, 1990 to 1994, Annual Report for Submission under the Framework Convention on Climate Change (1996), A.G. Salway, AEA Technology/UK Department of Environment.

4. Inventory of Technologies, Methods, and Practices for Reducing Emissions of Greenhouse Gases, A Report prepared for Working group II of the IPCC, Third External Review Draft, September 1995.

5. Personal Communication, Alison Moore, ETSU. 
6. Cost Effectiveness of Emission-Reducing Measures for Methane in The Netherlands, D. de Jaeger and K. Blok, Energy Conversion and Management, vol. 37, Nos.6-8 pp. 1181-1186, 1996.

7. Directive 75/442/EEC, amended by Directive 91/156/EEC, Articles 1 to 12 .

8. Methane Emissions from Land Disposal of Solid Wastes Draft Final Report produces for the International Energy Agency Greenhouse Gas R\&D Programma, ETSU, 1996.

9. Whalen, S.C., Reeurgh, W.S. and Sandbeck, K.A. (1990), Rapid Methane Oxidation in Landfill Cover Soil. Applied and Environmental Microbiology 56, pp.3405-3411.

10. Knightley, D., Nedwell, D.B. and Cooper, M. (1995). Capacity of methane oxidation in landfill cover soils measured in laboratory-scale microcosms. applied and Environmental Microbiology 61, pp.592-601.

11. Knightley, D. and Nedwell, D.B. (1995). Methane oxidation in landfill cover soils: can bacteria solve the emission problem? Environmental Managers Journal, 3, pp. 24-26.

12. EUROSTAT, 1996. Renewable Energy Source Statistics 1989-1994. EUROSTAT, Luxembourg.

13. Work carried out by AEA Technology in support of the UK Department of the Environment.

14. Methane Emissions from Coal Mining, Report Number PH2/5 (1996) IEA Greenhouse Gas R\&D Programme.

15. Energy statistics of OECD Countries - 1990-1991 and 1992-1993, IEA/OECD, Paris.

16. Digest of UK Energy Statistics 1994, HMSO, London.

17. National Submissions to Framework convention on Climate Change.

18. European Energy to 2020: A Scenario Approach, Energy in Europe, Special Issue, Spring 1996, DGXVII.

19. Emissions of Methane by the Oil and Gas System, Report Number PH2/7, January 1997, IEA Greenhouse Gas R\&D Programme.

20. Climate Change - the UK Programme UK's Second report under the Framework convention on Climate Change Cm 3558 (1997), HMSO, London.

21. Strategy Paper for Reducing Methane Emissions (Communication from the Commission to the Council and the European Parliament) COM(96) 557 final.

22. Proposal for a Council Directive on the Landfill of Waste, COM(97) 105 final.

23. CITEPA (1994). Strategies for Limiting Methane, B. Oudart, Final Report Contract No. B92/4 - 3040/16177. 